\title{
Biogas potential and methanogenic community shift in in-situ anaerobic sewage sludge digestion with food waste leachate additions
}

\author{
Ji Su Bae ${ }^{1}$, Yeo Myung Yoon², Seon Kyoung Shin ${ }^{1}$, Dong Jin Lee ${ }^{1^{*}}$ and Dong Cheol Seo $3,4^{*}$
}

\begin{abstract}
The objective of this study was to determine methane yields (MY) of organic wastes in biogasification facilities according to the mixing ratio of food waste/food waste leachate and sewage sludge. One biogasification facility that treated sewage sludge only was compared with three biogasification facilities treating sewage sludge and food waste. The theoretical MY was derived based on analyses of carbohydrate, fat, and protein to examine the efficiency of the biogasification facility. The average actual MY was $0.424 \mathrm{Sm}^{3} \mathrm{CH}_{4} / \mathrm{kg}$ volatile solids, which corresponded to $83.7 \%$ of theoretical MY. In the case of combined anaerobic digestion (CD) mixing with food waste/food waste leachate, inhibitory factors (volatile fatty acids [VFAs], total nitrogen [TN], and organic matter contents) showed the tendency to have relatively higher values in CD facilities than in the biogasification facility treating sewage sludge only. Mean concentrations of VFAs and TN in the anaerobic digester effluent, and the organic loading rate were $406 \mathrm{mg} / \mathrm{L}, 3,721 \mathrm{mg} / \mathrm{L}$, and $1.62 \mathrm{~kg}$ volatile solids $/ \mathrm{m}^{3}$ day, respectively. The influence of anaerobic digester effluent was in charge of $10 \%$ within the influent environmental loading rate from the sewage treatment plants associated with the biogasification facilities. Analyses of the microbial community showed that a remarkable change in the structure of methanogens was directly related to different MY in each plant. In particular, Methanoculleus and Methanosaeta increased with an increasing ratio of food waste/food waste leachate to sludge, while Methanococcus and Methanosarcina decreased. In conclusion, CD showed steady operational conditions and high efficiency of MY by injecting food waste/food waste leachate into the anaerobic digester. It met the current criteria for integrated treatment of organic waste in biogasification facilities in South Korea.
\end{abstract}

Keywords: Methane yield, Sewage sludge, Anaerobic digestion, Metagenome, Volatile solids

\section{Introduction}

Due to social aspects such as population growth, urbanization, and industrialization, the amount of organic wastes (containing sewage sludge and food waste) has

\footnotetext{
*Correspondence: dongj7@korea.kr; drseodc@gmail.com

1 Environmental Resources Research Department, National Institute of Environmental Research, Environmental Research Complex, Incheon 22689, Republic of Korea

${ }^{4}$ Division of Applied Life Science (BK21 Plus) \& Institute of Agriculture and Life Science, Gyeongsang National University, Jinju 52828, Republic of Korea

Full list of author information is available at the end of the article
}

been increasing annually in South Korea [1, 2]. In 2014, $10,112 \mathrm{ton} / \mathrm{d}$ of sewage sludge was generated, with an annual growth rate of $4.6 \%$ during the previous decade. Food waste was produced at a rate of 13,697.4 ton/d which accounted for $27.4 \%$ of municipal waste in Korea $[2,3]$. Ocean dumping and direct landfill of organic waste have been prohibited since 2012 in accordance with policy formulation [4-6]. Among land-based treatment methods including landfill and incineration, biogasification is a technology that can produce methane gas as a renewable energy through an anaerobic digestion 
process, and is a novel response to the current situation $[7,8]$.

Biogasification facilities in sewage treatment plants in South Korea have a low anaerobic digestion efficiency (only 54.2\%) compared to those in developed countries such as Europe due to relatively low influent concentrations with a low enrichment rate, a lack of knowledge on operating technology by process flow, and inadequate management $[9,10]$. In 2010, the Ministry of Environment (South Korea) promoted a master plan named 'energy-independent project to develop biogasification efficiency and utilize sewage sludge as biomass' [11]. In particular, sewage treatment without an anaerobic digestion tank is reviewed with treatment of food wastes. This involves establishment of anaerobic digestion in a sewage treatment plant for co-digestion with food wastes additions $[12,13]$.

In 2016, the number of biogasification facilities in South Korea that could treat organic wastes was increased by two (2.3\% increment) compared to the previous year (90 facilities). The total treatment capacity of biogasification facilities was 59,204 ton/day, which was an increase of $4.7 \%$ from the previous year. Among facilities for treating organic wastes, sewage sludge biogasification facility showed a high increase rate compared to other facilities for treating organic wastes. However, the average annual operation rate of biogasification facilities was only $32 \%$ [14].

The amount of biogas produced in sewage sludge biogasification facilities was $6.6 \mathrm{~m}^{3} /$ ton, which was considerably lower than that of food waste $\left(111.6 \mathrm{~m}^{3} /\right.$ ton $)$ and food waste leachate $\left(50.5 \mathrm{~m}^{3} /\right.$ ton $)[15,16]$. Combining the low concentration of sewage sludge with the high concentration of food wastes, the disadvantage of each organic waste is complemented. Thus, the operation efficiency of anaerobic digestion is improved and stable operation is achieved.

Therefore, the objective of this study was to accumulate in situ facility data on the effect of co-digestion of sewage sludge and food waste. The influence of water quality was also investigated in regard to the wastewater loading impact of re-circulated water after co-digestion with food wastes in the wastewater treatment plant. Metagenome analysis was performed to determine the effect of biogasification on co-digestion of sewage sludge and food waste in South Korea.

\section{Materials and methods}

\section{Target biogasification facilities and sampling method}

One sewage sludge biogasification facility (Busan, $35^{\circ} 07^{\prime}$ $33.5^{\prime \prime} \mathrm{N} 129^{\circ} 06^{\prime} 53.8^{\prime \prime} \mathrm{E}$ ), and three combined anaerobic digestion facilities (Seoul $\left[37^{\circ} 34^{\prime} 38.6^{\prime \prime} \mathrm{N} 126^{\circ} 49^{\prime} 33.3^{\prime \prime}\right.$ E], Bucheon [ $37^{\circ} 32^{\prime} 43.5^{\prime \prime} \mathrm{N} 126^{\circ} 45^{\prime} 55.9^{\prime \prime} \mathrm{E}$ ], and Ulsan $\left[35^{\circ} 27^{\prime} 39.4^{\prime \prime} \mathrm{N} 129^{\circ} 21^{\prime} 28.3^{\prime \prime} \mathrm{E}\right]$ ) were selected for this study. Sampling was carried out at the inlet and outlet of anaerobic digestion. Among the samples, effluent samples from the anaerobic digester were kept frozen for accuracy of microbial analysis. Remaining samples were refrigerated immediately after collection. Table 1 presents fundamental information regarding the four biogasification facilities which were selected for this investigation.

\section{Analysis methods of physicochemical properties}

Volatile solids (VS) were determined by 'Loss on ignition/volatile solids and total organics-gravimetry (ES 06301.1b)' and 'Humidity and total solid-gravimetry (ES

Table 1 Outline of target biogasification facilities

\begin{tabular}{|c|c|c|c|c|c|c|c|c|}
\hline Facility & $\begin{array}{l}\text { Treatment } \\
\text { materials }\end{array}$ & Type of digestion & $\begin{array}{l}\text { Mixing } \\
\text { ratio } \\
(\mathrm{SS}: F W(L))\end{array}$ & $\begin{array}{l}\text { Design capacity } \\
\text { of digester (ton/ } \\
\text { day) }\end{array}$ & $\begin{array}{l}\text { Volume } \\
\text { of digester } \\
\left(\mathrm{m}^{3}\right)\end{array}$ & HRT (day) & $\begin{array}{l}\text { Organic loading } \\
\text { rate }\left(\mathrm{kg}_{\mathrm{vs}} /\right. \\
\left.\mathrm{m}^{3} \text { day }\right)\end{array}$ & $\mathrm{pH}$ \\
\hline $\mathrm{SD}^{\mathrm{a}}$ & $\begin{array}{l}\text { Sewage sludge } \\
\text { (rWWTSS, } \\
\text { eWWTSS) }\end{array}$ & $\begin{array}{l}\text { Mesophilic, single } \\
\text { stage }\end{array}$ & - & 932 & 21,000 & 28 & 1.38 & $7.9( \pm 0.1)$ \\
\hline$C D^{b_{1}}$ & $\begin{array}{l}\text { Sewage sludge } \\
\text { (rWWTSS, } \\
\text { eWWTSS), food } \\
\text { waste leachate }\end{array}$ & $\begin{array}{l}\text { Mesophilic, single } \\
\text { stage }\end{array}$ & 0.965:0.035 & 7680 & 179,988 & 39 & 0.84 & $8.2( \pm 0.1)$ \\
\hline CD2 & $\begin{array}{l}\text { Sewage sludge } \\
\text { (rWWTSS), food } \\
\text { waste leachate }\end{array}$ & $\begin{array}{l}\text { Mesophilic, single } \\
\text { stage }\end{array}$ & $0.87: 0.13$ & 4205 & 82,776 & 27 & 1.40 & $8.1( \pm 0.3)$ \\
\hline CD3 & $\begin{array}{l}\text { Sewage sludge } \\
\text { (rWWTSS), food } \\
\text { waste }\end{array}$ & $\begin{array}{l}\text { Mesophilic, single } \\
\text { stage }\end{array}$ & $0.37: 0.63$ & 430 & 14,000 & 23 & 2.88 & $8.0( \pm 0.3)$ \\
\hline
\end{tabular}

\footnotetext{
a SD Anaerobic digestion facility treating sewage sludge only

b CD: Combined anaerobic digestion facility treating sewage sludge and food waste (leachate)

c rWWTSS Raw wastewater treatment sewage sludge, eWWTSS Excess wastewater treatment sewage sludge
} 
06303.1)' of the Korean Waste Standard Examination [17]. Chemical oxygen demand (COD) by chromium (CODcr) was analyzed according to the 'Titrimetric method (ES 04315.3b) of the Korean Official Test Water Pollution Standard [18]. Volatile fatty acids (VFAs), which is one of the impediment factors, and the observation index in the anaerobic digestion system, were analyzed by titration methods proposed in the Biogas Technical Guideline for Biogasification facilities in Germany [19]. In the titration method, samples were centrifuged at $10,000 \mathrm{~g}$ and were reacted with sulfuric acid $\left(0.1 \mathrm{~N} \mathrm{H}_{2} \mathrm{SO}_{4}\right)$ to measure VFA concentrations in the samples. Total nitrogen (TN) in samples was determined using the official testing method with respect to water pollution processes (ES 04363.1a) [18]. Nutrients including carbohydrate, protein, and fat were analyzed by the Korean Food Standard Codex [20].

\section{Calculation of sewage sludge treatment plant input loading rate}

The impact of the input loading rate of food waste in recycled water in the sewage sludge treatment plant was calculated as the ratio of the influent loading rate (biological oxygen demand [BOD], COD, suspended solids [SS], TN, and total phosphorus [TP]) of food waste in the recycled water and the influent loading rate in the sewage sludge treatment plant. Various factors were necessary to calculate the input loading rate of recycled water from the anaerobic digestion system. Data for each factor was collected during a field survey and included the sewage disposal plant capacity, design concentrations of input sewage, and flux and concentration of recycled water.

\section{Theoretical methane yield}

According to various literature reviews, methane and carbon dioxide are generated from organic wastes such as food waste and sewage sludge in anaerobic conditions. The theoretical MY of organic wastes is defined for specific compositions of microorganism substrates. Angelidaki and Sanders [21] and Tchobanoglous et al. [22] suggested Eq. (1) for the calculation of the theoretical MY. This equation is derived assuming that total organic materials were converted to $\mathrm{CO}_{2}$ and $\mathrm{CH}_{4}$ with $\mathrm{H}_{2} \mathrm{O}$ as an external source. analyses. The theoretical MY representative of a standard status $\left(0{ }^{\circ} \mathrm{C}, 1 \mathrm{~atm}\right)$ was calculated following Eq. (2).

$$
\begin{aligned}
& \text { Theoretical methane gas production }\left(\mathrm{STP} \mathrm{L} \cdot \mathrm{CH}_{4} / \mathrm{g} \cdot \mathrm{VS}\right) \\
& =22.4\{[(4 \mathrm{a}+\mathrm{b}-2 \mathrm{c}-3 \mathrm{~d}) / 8] /[12 \mathrm{a}+\mathrm{b}+16 \mathrm{c}+14 \mathrm{~d}]\}
\end{aligned}
$$

\section{Practical MY}

In this study, the following field data were used to estimate the actual MY of target facilities; input treatment amount of organic waste (ton/day), VS contents (\%) of the inlet and outlet of the anaerobic digestion system, biogas production $\left(\mathrm{m}^{3}\right)$, and biogas composition (\%) especially methane. The field data were mainly selected from the normal operating data for the 12-month period from 2015-2016.

\section{Metagenome analysis}

The samples collected from each full-scale anaerobic digestion plant were extracted and purified using Ultraclean Soil DNA Kit (Mo Bio Laboratory Inc., USA) and UltraClean Microbial DNA Isolation Kit (Mo Bio Laboratory Inc., USA) according to the manufacturer's instructions. A $20 \mathrm{ng}$ aliquot of each DNA sample was sampled and injected for PCR reaction. The $16 \mathrm{~S}$ universal primers 27F (5' GAGTTTGATCMTGGCTCAG $\left.3^{\prime}\right)$ and 800R $\left(5^{\prime}\right.$ TACCAGGGTATCTAATCC $3^{\prime}$ ) for bacteria; and Arc8f (5'-TTCCGGTTGATCCYGCCGGA-3') and Arc519r (5'-TTACCGCGGCKGCTG-3') for archaea, were used for the $16 \mathrm{~s}$ rRNA genes amplification [23, 24]. The Fast Start High Fidelity PCR System (Roche, Switzerland) was utilized for PCR under three steps: $94{ }^{\circ} \mathrm{C}$ for $3 \mathrm{~min}$ for 35 cycles at $94{ }^{\circ} \mathrm{C}$ for $15 \mathrm{~s}, 55^{\circ} \mathrm{C}$ for $45 \mathrm{~s}$ and $72{ }^{\circ} \mathrm{C}$ for $1 \mathrm{~min}$, and a final elongation step at $72{ }^{\circ} \mathrm{C}$ for $8 \mathrm{~min}$. After PCR, products were processed using a miseq system (Illumina, CA, USA) by commercial company (Macrogen, Korea). Operational taxonomic units (OTUs) were then trimmed and identified by using QIIME software.

\section{Results and discussion \\ Operation factors of target biogasification facilities}

To determine the operation factors of target biogasification facilities, VS, CODcr, total nutrient contents, and VFAs were analyzed. Table 2 shows the removal efficien-

$$
\begin{array}{r}
\mathrm{C}_{\mathrm{a}} \mathrm{H}_{\mathrm{b}} \mathrm{O}_{\mathrm{c}} \mathrm{N}_{\mathrm{d}}+[(4 \mathrm{a}-\mathrm{b}-2 \mathrm{c}+3 \mathrm{~d}) / 4] \mathrm{H}_{2} \mathrm{O} \rightarrow[(4 \mathrm{a}+\mathrm{b}-2 \mathrm{c}-3 \mathrm{~d}) / 8] \\
\mathrm{CH}_{4}+[(4 \mathrm{a}-\mathrm{b}+2 \mathrm{c}+3 \mathrm{~d}) / 8] \mathrm{CO}_{2}+\mathrm{dNH}_{4}
\end{array}
$$

Here, a, b, c, and d are the molecular amounts of carbon, hydrogen, oxygen, and nitrogen, respectively. In this study, the organic formula described above was expressed on a molar basis using the results of nutrient content cies and concentrations of VS and CODcr in the target digestion system.

VS contents in biogasification facilities were $2.07 \%$ in $\mathrm{SD}$ and $5.21 \%$ in $\mathrm{CD}$. CODcr concentrations were 
Table 2 Operation status of biogasification facilities

\begin{tabular}{|c|c|c|c|c|c|c|c|c|}
\hline \multirow[t]{2}{*}{ Seasons $^{a}$} & \multicolumn{4}{|l|}{$\mathrm{SD}^{\mathbf{b}}$} & \multicolumn{4}{|l|}{$C D^{c}$} \\
\hline & VS (\%) & DRE $^{d}$ of VS (\%) & COD (mg/L) & $\begin{array}{l}\text { DRE } \\
\text { of CODcr (\%) }\end{array}$ & VS (\%) & DRE of VS (\%) & COD (mg/L) & $\begin{array}{l}\text { DRE } \\
\text { of CODcr } \\
(\%)\end{array}$ \\
\hline WIN-in & 1.28 & 42.56 & 14,108 & 35.90 & 5.40 & 62.81 & 45,963 & 52.62 \\
\hline WIN-out & 0.74 & - & 9044 & - & 2.01 & - & 21,777 & - \\
\hline SPR-in & 2.78 & 44.32 & 49,488 & 78.72 & 5.49 & 62.08 & 70,116 & 66.22 \\
\hline SPR-out & 1.55 & - & 10,532 & - & 2.08 & - & 23,685 & - \\
\hline SUM-in & 1.87 & 17.11 & 27,638 & 18.18 & 5.73 & 71.86 & 57,629 & 55.39 \\
\hline SUM-out & 1.55 & - & 22,613 & - & 1.61 & - & 25,708 & - \\
\hline AUT-in & 2.34 & 50.85 & 41,205 & 26.71 & 4.19 & 54.93 & 53,876 & 59.21 \\
\hline AUT-out & 1.15 & - & 30,200 & - & 1.89 & - & 21,974 & - \\
\hline Average-in & 2.07 & 38.71 & 33,110 & 39.88 & 5.21 & 62.92 & 56,896 & 58.36 \\
\hline Average-out & 1.25 & - & 18,097 & - & 1.90 & - & 23,286 & - \\
\hline
\end{tabular}

a WIN: Winter, SPR: Spring, SUM: Summer, AUT: Autumn

b SD: Anaerobic digestion facility treating sewage sludge only

c CD: Combined anaerobic digestion facility treating sewage sludge and food waste (leachate)

d DRE: Degradation efficiency of anaerobic digester

$33,110 \mathrm{mg} / \mathrm{L}$ in SD and $56,896 \mathrm{mg} / \mathrm{L}$ in CD. In each season, the organic material concentration of $C D$ was higher than that of the SD using sewage sludge as the substrate. Especially, the lowest concentration of input substrate in winter was $14,108 \mathrm{mg} / \mathrm{L}$ as CODcr and $1.28 \%$ as VS. VS and CODcr of input substrate in biogasification facilities tended to increase in the order of winter $<$ summer $<$ autumn $<$ spring. In terms of removal efficiency, the VS and CODcr fluctuations in SD were large. On the contrary, the seasonal removal efficiency did not change significantly by treatment sewage sludge with high organic matter together.

The nutrient contents in samples are presented in Fig. 1. The mean contents of nutrients in SD were $1.62 \mathrm{~g} / 100 \mathrm{~g}(44.9 \%)$ as protein, $0.92 \mathrm{~g} / 100 \mathrm{~g}(25.5 \%)$ as fat, and $1.07 \mathrm{~g} / 100 \mathrm{~g}(29.6 \%)$ as carbohydrate. In the case of the CD input substrate, the mean weights of nutrients were $1.80 \mathrm{~g} / 100 \mathrm{~g}(40.1 \%)$ as protein, $1.48 \mathrm{~g} / 100 \mathrm{~g}$ (33.0\%) as fat, and $1.20 \mathrm{~g} / 100 \mathrm{~g}(26.9 \%)$ as carbohydrates.

The mean total contents of nutrients in samples were $3.60 \mathrm{~g} / 100 \mathrm{~g}$ in SD and $4.48 \mathrm{~g} / 100 \mathrm{~g}$ in CD. As a result of the degradation efficiency depending on mixing with food wastes, fat and carbohydrate were degraded by $31.74 \%$ and $37.44 \%$, respectively, compared to SD. Especially, the protein removal efficiency was increased by approximately 1.5 times compared to that of fat and carbohydrate.

VFAs and TN are the main factors that ensure that decomposition process of organic materials proceeds stably inside the anaerobic digester. When high VFAs and TN concentrations accumulate in the anaerobic digester,
VFAs act as an inhibitory substance which decrease methanogens activity and the decomposition rate of organic matter during hydrolysis and acidification procedures [21]. VFAs concentrations in the target anaerobic digester effluent were $352 \mathrm{mg} / \mathrm{L}$ in SD and $424 \mathrm{mg} / \mathrm{L}$ in $\mathrm{CD}$, which means that the removal efficiency of organic matter inside the anaerobic digester was lower than that of the CD system due to the low input of VFAs in SD.

Nitrogen content is one of the evaluation factors related with associated wastewater treatment following an anaerobic digestion system. The TN concentration in the $\mathrm{CD}$ was $4359 \mathrm{mg} / \mathrm{L}$ in the anaerobic digestion effluent and $1747 \mathrm{mg} / \mathrm{L}$ in the final wastewater. These concentrations are approximately 2.4 times and 1.3 times higher, respectively, than the $\mathrm{TN}$ concentration in the sewage sludge digestion system.

\section{Impact loading rate into the sewage sludge treatment plants}

Anaerobic digester effluent is discharged as wastewater and dehydrated sludge cake through the dewatering system in the biogasification facility. Especially, the wastewater which is the final effluent of the anaerobic digestion system, is transferred to the grit chamber or the first settling reservoir of the sewage treatment plant, which is located near the biogasification facility. According to the technical design and operation guidelines of biogasification facilities in Korea [25], it suggested that anaerobic digester effluent should be within $10 \%$ of influent environmental loading rate in sewage treatment plants. 


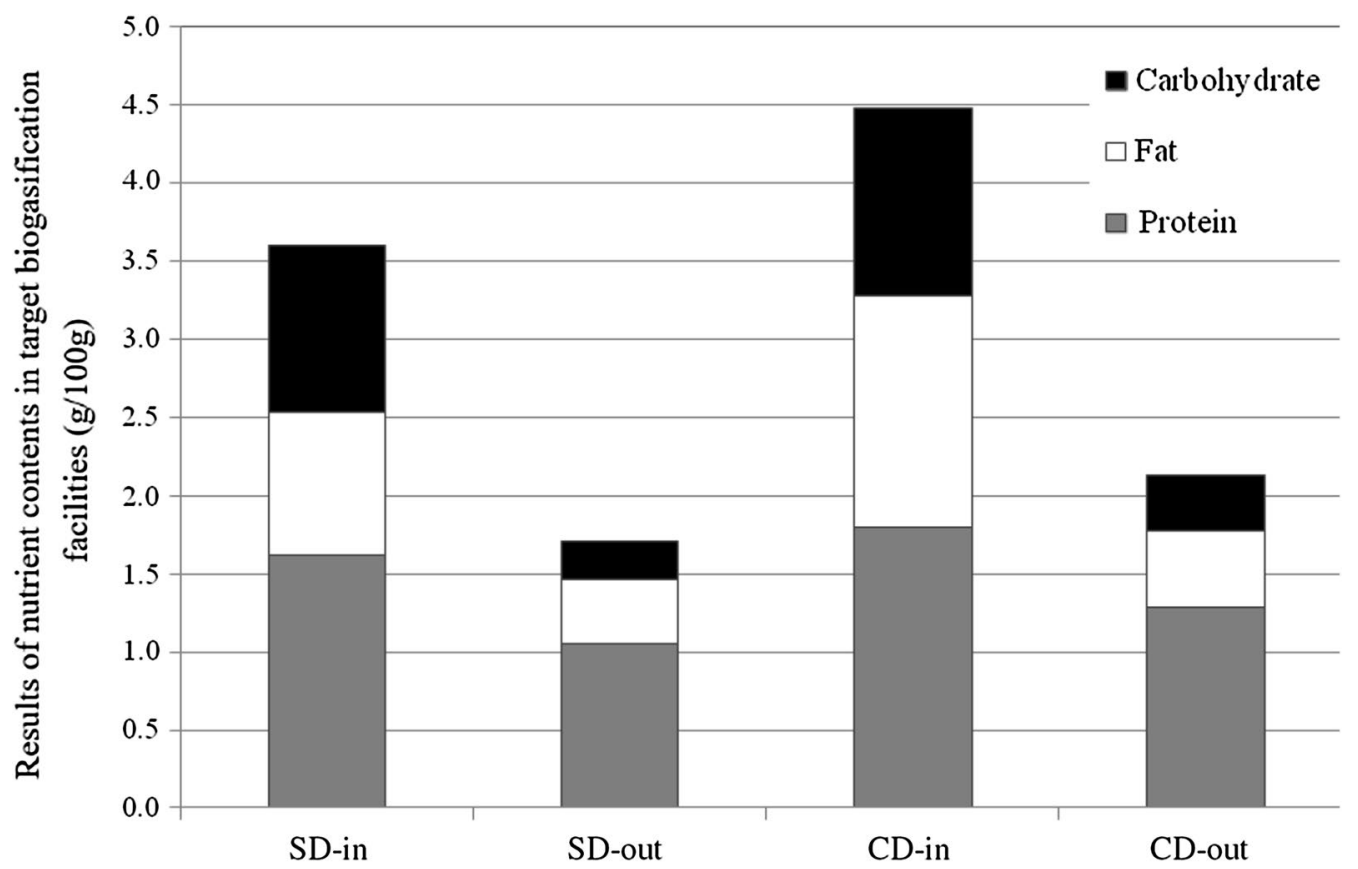

Fig. 1 Results of nutrient contents in target biogasification facilities. *SD: Anaerobic digestion facility treating sewage sludge only. ${ }^{*} C D$ : Combined anaerobic digestion facility treating sewage sludge and food waste (leachate)

Table 3 shows the impact of anaerobic digestion effluent on environmental loading input in the sewage treatment plant. Five water quality factors (i.e., biochemical oxygen demand [BOD], COD, suspended solid [SS], TN, and TP) were collected and reconstructed the operation field data of the target facilities. The influences of anaerobic digester effluent in SD were $0.7 \%$ in BOD, $0.6 \%$ in COD, $0.7 \%$ in SS, $6.2 \%$ in TN, and $4.5 \%$ in TP. On the other hand, the mean influences in $\mathrm{CD}$ were $1.3 \%$ in BOD, $1.0 \%$ in COD, $1.4 \%$ in SS, $6.5 \%$ in $\mathrm{TN}$, and $4.5 \%$ in TP. The effects of the load factor on food waste addition were $0.6 \%, 0.4 \%$, and $0.7 \%$ in BOD, COD, and SS, respectively, and $0.3 \%$ in $\mathrm{TN}$ and $0 \%$ in TP.

\section{Theoretical MY}

The theoretical MY was calculated based on the postulation that input organic wastes were $100 \%$ decomposed during the anaerobic digestion procedure. In this study, MY was estimated by mass per composition and molar ratio of nutrients (protein, fat, and carbohydrate) according to Angelidaki and Sanders [21]. The specific theoretical MY and characteristics of substrate components are described in Table 4.

Table 5 presents the calculation results of the theoretical MY in the target biogasification facilities. The theoretical MY of each nutrient were $0.496 \mathrm{Sm}^{3} \mathrm{CH}_{4} / \mathrm{kg}$ VS as protein, $1.014 \mathrm{Sm}^{3} \mathrm{CH}_{4} / \mathrm{kg}$ VS as fat, and $0.415 \mathrm{Sm}^{3} \mathrm{CH}_{4} /$ $\mathrm{kg}$ VS as carbohydrate. Based on the nutrients analysis results and the data in Table 3, the mean mass and molar ratios (protein: fat: carbohydrate) were 0.40:0.32:0.27 and 0.64:0.07:0.30, respectively. The mean potential theoretical MY by the nutrient compositions was $0.507 \mathrm{Sm}^{3} \mathrm{CH}_{4} /$ $\mathrm{kg}$ VS. The theoretical MY was estimated to be $0.496 \mathrm{Sm}^{3} \mathrm{CH}_{4} / \mathrm{kg}$ VS in the case of anaerobic digestion of sewage sludge only. However, the same value for the combined anaerobic digesters was $0.510 \mathrm{Sm}^{3} \mathrm{CH}_{4} / \mathrm{kg} \mathrm{VS}$, which showed no difference from the SD.

\section{Actual MY}

The actual MY in biogasification facilities were calculated based on dry gas and standard conditions at $0{ }^{\circ} \mathrm{C}$ and $1 \mathrm{~atm}$ and are shown in Table 6. The mean actual MY based on VS in target biogasification facilities was $0.424 \mathrm{Sm}^{3} \mathrm{CH}_{4} / \mathrm{kg}$ VS. Depending on whether sewage sludge and food waste (leachate) were mixed, the actual MY in CD was $0.478 \mathrm{Sm}^{3} \mathrm{CH}_{4} / \mathrm{kg}$ VS, which is 1.8 times greater than that of SD.

Compared with the theoretical values shown in Table 4, the actual MY in each facility was quite different in accordance with the substrate status. In the case of SD, the actual MY was $0.262 \mathrm{Sm}^{3} \mathrm{CH}_{4} / \mathrm{kg}$ VS, which accounted for $52.7 \%$ of the theoretical value in the SD facility. In contrast, the actual MY corresponded with theoretical values by up to $93.7 \%$ by increasing the ratio of food waste (leachate) in the organic substrate. These results demonstrate that mixing the input substrate with 
Table 3 Impact on environmental loading of dewatered wastewater on nearby sewage treatment plants

\begin{tabular}{|c|c|c|c|c|c|c|c|}
\hline Facility & SD & CD1 & CD2 & CD3 & Avg & Min & Max \\
\hline Capacity of sewage disposal plant (1000 m³/d) & 340 & 1630 & 680 & 250 & 725 & 250 & 1630 \\
\hline \multicolumn{8}{|l|}{ Design concentration of input sewage (mg/L) } \\
\hline BOD & 125 & 174 & 180 & 160 & 160 & 125 & 180 \\
\hline COD & 110 & 94 & 160 & 150 & 129 & 94 & 160 \\
\hline SS & 147 & 133 & 180 & 180 & 160 & 133 & 180 \\
\hline $\mathrm{TN}$ & 38 & 37 & 40 & 50 & 41 & 37 & 50 \\
\hline $\mathrm{TP}$ & 5 & 4 & 5 & 6 & 5 & 4 & 6 \\
\hline \multicolumn{8}{|l|}{ Design influent loading rate of input sewage $(\mathrm{kg} / \mathrm{d})(\mathrm{A})$} \\
\hline BOD & 42,500 & 283,620 & 122,400 & 40,000 & 122,130 & 40,000 & 283,620 \\
\hline COD & 37,400 & 153,220 & 108,800 & 37,500 & 84,230 & 37,400 & 153,220 \\
\hline SS & 49,980 & 216,790 & 122,400 & 45,000 & 108,543 & 45,000 & 216,790 \\
\hline $\mathrm{TN}$ & 12,920 & 60,310 & 27,200 & 12,500 & 28,233 & 12,500 & 60,310 \\
\hline $\mathrm{TP}$ & 1700 & 6846 & 3400 & 1375 & 3330 & 1375 & 6846 \\
\hline Recycle water flux after anaerobic digestion $\left(\mathrm{m}^{3} / \mathrm{d}\right)$ & 900 & 4600 & 1742 & 600 & 1961 & 600 & 4600 \\
\hline Mixing ratio of food waste (leachate) in organic materials (\%) & - & 4 & 26 & 63 & 31 & 4 & 63 \\
\hline \multicolumn{8}{|l|}{ Concentration of recycle water (mg/L) } \\
\hline BOD & 322 & 307 & 1129 & 1450 & 802 & 307 & 1450 \\
\hline COD & 262 & 226 & 523 & 1205 & 554 & 226 & 1205 \\
\hline SS & 373 & 386 & 1250 & 1750 & 940 & 373 & 1750 \\
\hline $\mathrm{TN}$ & 895 & 408 & 1056 & 2012 & 1093 & 408 & 2012 \\
\hline $\mathrm{TP}$ & 85 & 93 & 52 & 102 & 83 & 52 & 102 \\
\hline \multicolumn{8}{|l|}{ Influent loading rate of recycle water $(\mathrm{kg} / \mathrm{d})(\mathrm{B})$} \\
\hline BOD & 290 & 1410 & 1967 & 870 & 1134 & 290 & 1967 \\
\hline COD & 236 & 1037 & 911 & 723 & 727 & 236 & 1037 \\
\hline SS & 336 & 1776 & 2178 & 1050 & 1335 & 336 & 2178 \\
\hline $\mathrm{TN}$ & 806 & 1878 & 1840 & 1207 & 1433 & 806 & 1878 \\
\hline $\mathrm{TP}$ & 77 & 428 & 91 & 61 & 164 & 61 & 428 \\
\hline \multicolumn{8}{|l|}{ Percentage of recycle water to influent loading rate $(B / A) * 100(\%)$} \\
\hline BOD & 0.7 & 0.5 & 1.6 & 2.2 & 1.3 & 0.5 & 2.2 \\
\hline COD & 0.6 & 0.7 & 0.8 & 1.9 & 1.0 & 0.6 & 1.9 \\
\hline SS & 0.7 & 0.8 & 1.8 & 2.3 & 1.4 & 0.7 & 2.3 \\
\hline $\mathrm{TN}$ & 6.2 & 3.1 & 6.8 & 9.7 & 6.5 & 3.1 & 9.7 \\
\hline $\mathrm{TP}$ & 4.5 & 6.2 & 2.7 & 4.5 & 4.5 & 2.7 & 6.2 \\
\hline
\end{tabular}

\begin{tabular}{|c|c|c|c|c|}
\hline Nutrients & $\begin{array}{l}\text { Chemical } \\
\text { formula }\end{array}$ & $\begin{array}{l}\text { Mass } \\
\text { of } 1 \mathrm{~mol}(\mathrm{~g} / \\
\text { mole })^{\mathbf{b}}\end{array}$ & $\begin{array}{l}\text { Methane } \\
\text { yield } \\
\left(\mathrm{Sm}^{3} \mathrm{CH}_{4} /\right. \\
\text { kgVS) }\end{array}$ & $\begin{array}{l}\mathrm{CH}_{4} \\
\text { content } \\
(\%)^{\mathrm{b}}\end{array}$ \\
\hline Carbohydrate & $\left(\mathrm{C}_{6} \mathrm{H}_{10} \mathrm{O}_{5}\right) \mathrm{n}$ & 162 & 0.415 & 50 \\
\hline Protein $^{a}$ & $\mathrm{C}_{5} \mathrm{H}_{7} \mathrm{NO}_{2}$ & 113 & 0.496 & 50 \\
\hline Fat & $\mathrm{C}_{57} \mathrm{H}_{104} \mathrm{O}_{6}$ & 884 & 1.014 & 70 \\
\hline
\end{tabular}

a It assume that nitrogen is converted to $\mathrm{NH}_{3}$

b Angelidaki et al. [22] high-nutrient food waste (leachate) is more efficient for anaerobic microorganisms such as acid-producing bacteria and methanogenic bacteria inside the anaerobic digester.

\section{Metagenome analysis}

To reveal how the microbial structure differed among four full-scale anaerobic digestion plants in terms of the response to the effect of different feedstock compositions, microbial community analysis was conducted by a next generation sequencing technique (NGS). A total of 86,309 high-quality sequence reads and 387 OTUs in bacteria and 185 OTUs in archaea with similarity cutoffs of $3 \%$ were obtained (data not shown). The result of alpha 
Table 5 Theoretical methane yield in target biogasification facilities based on the nutrient contents

\begin{tabular}{|c|c|c|c|c|c|c|}
\hline \multirow[t]{2}{*}{ Sample $^{a}$} & \multicolumn{3}{|c|}{ Mass per composition in samples $(\mathrm{g} / 100)$} & \multirow[t]{2}{*}{ Molar ratio } & \multirow[t]{2}{*}{ Mass ratio } & \multirow{2}{*}{$\begin{array}{l}\text { Theoretical methane } \\
\text { yield }\left(\mathrm{Sm}^{3} \mathrm{CH}_{4} / \mathrm{kgVS}\right)\end{array}$} \\
\hline & Protein & Fat & Carbohydrate & & & \\
\hline SD1 & 1.26 & 0.70 & 0.82 & 0.66: 0.04: 0.30 & 0.45:0.25:0.30 & 0.496 \\
\hline CD1 & 2.06 & 1.15 & 0.64 & $0.78: 0.05: 0.17$ & $0.54: 0.30: 0.16$ & 0.511 \\
\hline $\mathrm{CD} 2$ & 1.09 & 1.68 & 0.98 & $0.55: 0.11: 0.34$ & $0.29: 0.45: 0.26$ & 0.524 \\
\hline CD3 & 2.01 & 1.62 & 1.92 & $0.56: 0.06: 0.38$ & $0.36: 0.29: 0.35$ & 0.496 \\
\hline Average & 1.61 & 1.28 & 1.09 & - & - & 0.507 \\
\hline
\end{tabular}

CD: Combined anaerobic digestion facility treating sewage sludge and food waste (leachate)

a SD: Anaerobic digestion facility treating sewage sludge only

b The average molar ratio by components of food waste extracted in biogasification facilities was applied

Table 6 Actual methane yield based on VS in target biogasification facilities

\begin{tabular}{|c|c|c|}
\hline Sample & $\begin{array}{l}\text { Methane yield } \\
\left(\mathrm{Sm}^{3} \mathrm{CH}_{4} / \mathrm{kgVS}_{\mathrm{in}}{ }^{\mathrm{b}}\right)\end{array}$ & $\begin{array}{l}\text { Methane yield } \\
\left(\mathrm{Sm}^{3} \mathrm{CH}_{4} / \mathrm{kgVS}_{\text {rem }}{ }^{\mathrm{c}}\right)\end{array}$ \\
\hline $\mathrm{SD}^{\mathrm{a}}$ & 0.10 & 0.262 \\
\hline CD1 & 0.22 & 0.423 \\
\hline $\mathrm{CD} 2$ & 0.30 & 0.538 \\
\hline CD3 & 0.34 & 0.475 \\
\hline Average & 0.24 & 0.424 \\
\hline
\end{tabular}

CD: Combined anaerobic digestion facility treating sewage sludge and food waste (leachate)

a SD: Anaerobic digestion facility treating sewage sludge only

b $\mathrm{VS}_{\mathrm{in}}$ : based on values analyzed from sample of inlet

${ }^{c} \mathrm{VS}_{\text {rem }}$ : based on values calculated from removed VS

diversity analysis showed higher microbial diversity in samples of CD1, with 94 bacterial and 42 archaeal OTUs in comparison to samples from SD (77 bacterial and 39 archaeal OTUs), showing that both bacterial and archaeal diversity of co-digestion were higher than in single digestion anaerobic digestion. Besides, 101 OTUs of bacteria and 49 OTUs of archaea in CD2 and 115 OTUs of bacteria and 55 OTUs of archaea in CD3 were observed. This phenomenon indicates that as more food waste was added to the anaerobic digestion plants, the microbial structure became more diverse.

Figure 2 shows the different core bacteria existing in the four full-scale anaerobic digestion systems. The taxonomic assignment in SD showed that the vast majority of the bacterial community belonged to the genus Candidatus Accumulibacter (26.2\%), Petrotoga (8.3\%), and Acholeplasma (8.0\%) as shown in Fig. 2a. As food waste was added as a co-substrate, those members decreased while increases in other bacterial members were observed; however, those patterns were irregular in each plant. The relative abundances of Levilinea and Thermovirga increased in CD1, accounting for $24.5 \%$ and $10.9 \%$, respectively. In $\mathrm{CD} 2$, genus belonging to Cloacibacillus (25.2\%), Aminivibrio (6.4\%), and Treponema (5.4\%) became the vast majority of the bacteria. Meanwhile, genera Mesotoga (63.0\%) was the predominant genera in CD3.

In general, changes in the community of methanogenic archaea is directly related to the MY in each anaerobic digestion plant. Figure $2 \mathrm{~b}$ shows a more remarkable change in the archaeal structure at the genus level, and different patterns in the relative abundance were observed in each plant compared to the results of the bacterial taxonomic assignment. There was an apparent decrease in the relative abundance of genera belonging to Methanococcus $(45.1 \%, 64.1 \%$, and $16.0 \%$ in CD1, $\mathrm{CD} 2$, and CD3, respectively), which was $72.5 \%$ in SD. The second-largest sequences belonging to Methanosarcina in SD also decreased in all CDs, but varied from $0.2-1.1 \%$. Methanosarcina are known as the most metabolically versatile methanogens and can produce $\mathrm{CH}_{4}$ by means of both hydrogenotrophic and aceticlastic pathways. A high abundance of Methanosarcina are often related to an adaptation response to stress such as fluctuations in substrate, or accumulation or shock loading of organic acids [26]. Instead, sequences belonging to Methanosaeta and Methanoculleus increased with the increasing ratio of food waste to sludge, occupying $4.2 \%$ and $5.1 \%$ in CD1, $4.9 \%$ and $9.3 \%$ in $\mathrm{CD} 2$, and $12.8 \%$ and $23.1 \%$ in CD3, respectively. It has been reported that when the carbohydrate composition increased in feedstock, the anaerobic digestion community was dominated by Methanoculleus and Methanosaeta [27]. In particular, Methanosaeta have been reported as efficient methanogens which exclusively use acetate as a substrate for $\mathrm{CH}_{4}$ production, and have been observed at low acetate concentrations [28].

\section{Comparative studies of MY of sewage sludge and food waste (leachate)}

Table 7 presents the research results of MY in various preliminary studies in South Korea. Kim et al., Byun 


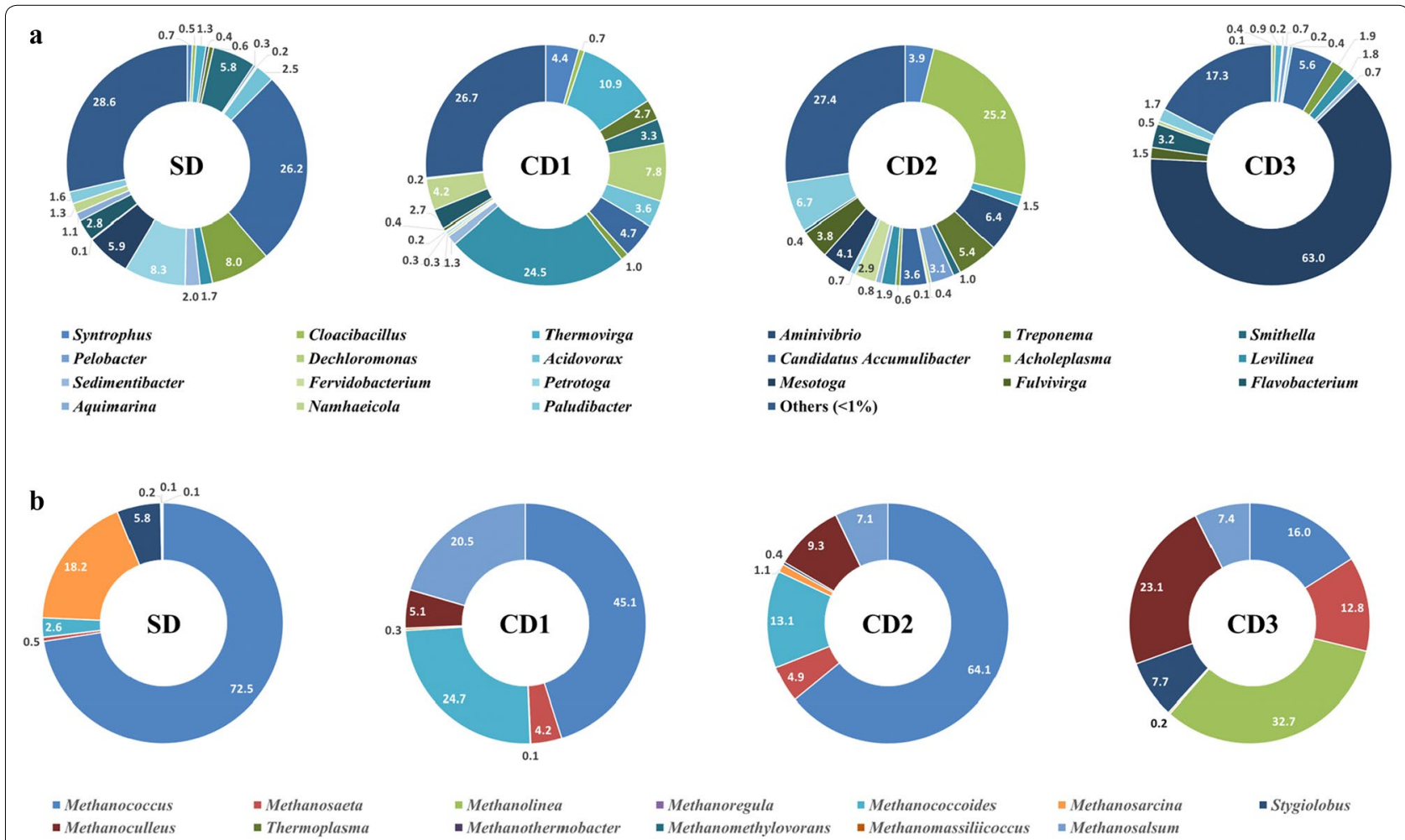

Fig. 2 Results of microbial community analysis in four full-scale anaerobic digestion plants. a Bacterial community, b Archaeal community

Table 7 Comparative other studies on biogasification of sewage sludge and food waste (leachate)

\begin{tabular}{|c|c|c|c|c|c|c|}
\hline Sample & $\begin{array}{l}\text { Methane yield } \\
\left(\mathrm{Sm}^{3} \mathrm{CH}_{4} / \mathrm{kgVS}\right)\end{array}$ & Temp $\left({ }^{\circ} \mathrm{C}\right)$ & HRT (day) & $\mathrm{C} / \mathrm{N}$ ratio & $\begin{array}{l}\text { Removal } \\
\text { efficiency of VS } \\
\text { (\%) }\end{array}$ & Reference \\
\hline Municipal wastewater sludge (1) & 0.232 & 35 & 24 & 6.7 & - & Kim et al. [29] \\
\hline Municipal wastewater sludge (2) & 0.181 & 35 & 24 & 5.0 & - & \\
\hline Wastewater sludge with food waste leachate & 0.396 & 35 & 24 & 8.3 & - & \\
\hline Sewage sludge with food waste leachate (1:9) & 0.233 & 55 & 30 & 6.0 & 72.5 & Lee et al. [7] \\
\hline Sewage sludge with food waste leachate (3:7) & 0.298 & 55 & 30 & 7.4 & 84.3 & \\
\hline Sewage sludge with food waste leachate (5:5) & 0.344 & 55 & 30 & 9.4 & 89.0 & \\
\hline Sewage sludge & 0.180 & 35 & 30 & - & 47.6 & Byun et al. [30] \\
\hline Sewage sludge with food waste leachate (5:5) & 0.223 & 35 & 30 & - & 63.4 & \\
\hline Sewage sludge & 0.186 & 35 & - & - & 35.4 & Kim et al. [31] \\
\hline Sewage sludge with food waste $(0.87: 0.13)$ & 0.201 & 35 & - & - & 39.9 & \\
\hline Sewage sludge only & 0.262 & Mesophilic & 28 & 7.3 & 38.7 & This study \\
\hline Sewage sludge mixing with food waste leachate & 0.478 & Mesophilic & 30 & 9.1 & 59.6 & \\
\hline
\end{tabular}

et al., and Kim et al. determined the MY with or without the addition of food waste leachate [29-35]. Especially, Kim et al. [29] examined the $\mathrm{C} / \mathrm{N}$ ratio of input substrate for evaluating the impact on methane production. Inherent MY of sewage sludge in previous research have been shown in the range of $0.180 \sim 0.232 \mathrm{Sm}^{3} \mathrm{CH}_{4} / \mathrm{kg} \mathrm{VS}$ at $35.4 \sim 47.6 \%$ VS degradation efficiency.
Kim et al. [31] estimated the feasibility of co-digestion of sewage sludge and food waste. Combined anaerobic digestion of sewage sludge and food waste enhanced the MY and COD removal efficiency by approximately 1.1 times compared to that of anaerobic digestion of sewage sludge only. Lee et al. [35] carried out a biochemical methane potential test under thermophilic temperature conditions $\left(55^{\circ} \mathrm{C}\right)$. At a substrate ratio of 
up to 5:5, MY was increased from $0.233 \mathrm{Sm}^{3} \mathrm{CH}_{4} / \mathrm{kg}$ VS to $0.344 \mathrm{Sm}^{3} \mathrm{CH}_{4} / \mathrm{kg}$ VS, exhibiting a 1.5 times improvement in results. Comparing the MY in this study with existing case studies, it can be seen that the overall flow was similar in terms of factors such as MY, removal rate, and the $\mathrm{C} / \mathrm{N}$ ratio.

\section{Acknowledgements}

This work was supported by a grant from the National Institute of Environment Research (NIER), funded by the Ministry of Environment (MOE) of the Republic of Korea (NIER-2016-01-01-038).

\section{Authors' contributions}

J-SB, Y-MY, S-KS, D-JL and D-CS designed and conducted the experiment as well as wrote the manuscript. D-JL and D-CS inspired the overall work and revised the final manuscript. All authors helped prepare the manuscript. All authors read and approved the final manuscript.

\section{Funding}

Not applicable

\section{Availability of data and materials}

All data is available in the main text.

\section{Competing interests}

The authors declare that they have no competing interests.

\begin{abstract}
Author details
${ }^{1}$ Environmental Resources Research Department, National Institute of Environmental Research, Environmental Research Complex, Incheon 22689, Republic of Korea. ${ }^{2}$ Environmental Engineering, Chungbuk National University, Chungdae-ro 1, Seowon-Gu, Cheongju, Chungbuk 28644, Republic of Korea. ${ }^{3}$ Department of Agricultural Chemistry and Food Science \& Technology, Gyeongsang National University, Jinju 52828, Republic of Korea. ${ }^{4}$ Division of Applied Life Science (BK21 Plus) \& Institute of Agriculture and Life Science, Gyeongsang National University, Jinju 52828, Republic of Korea.
\end{abstract}

Received: 4 August 2020 Accepted: 12 September 2020

Published online: 26 September 2020

\section{References}

1. Korea Ministry of Environment (2014) A study on the co-digestion of sewage sludge and manure

2. Korea Ministry of Environment (2015) 2014 Status of waste generation and disposal in South Korea

3. Korea Ministry of Environment (2015) 2014 Sewage statistics

4. Lee JM, Lee KY, Yoo YS (2013) Ocean dumping prohibition of waste and future task. Gyeonggi Research Institute 80:1-20

5. Lee JM, Lee KY, So HJ (2012) A study on waste management for prohibiting ocean dumping. Gyeonggi Res Inst. 11:1-138

6. Korea Ministry of Environment (2008) A study on economic analysis of waste business

7. Lee CY, Chung WJ, Kim JT (2016) A study on the development trends of wastewater sludge treatment technology. J Korean Geo-Environ Soc 17(8):5-15

8. Hong JS, Kim HG (2012) Analysis of R\&D investment of waste reduce, recycle and energy recovery technology. J Energ Eng 21(3):315-324

9. Korea Ministry of Environment (2011) Analysis of actual operation status of public sewage treatment plant in 2010

10. Cho IH, Ko IB, Kim JT (2014) Technology trend on the increase of biogas production and sludge reduction in wastewater treatment plants: sludge pre-treatment techniques. Korean Chem Eng Res 52(4):413-424

11. National Assembly Budget office (2012) Problems and improvement tasks of establishment of organic waste biogasification facility-focusing on economic feasibility analysis

12. Korea Ministry of Environment (2010) Basic plan for energy independence
13. Lee KY, Lee SH, Cho YM, Choi KS (2011) Improvement of digestion tank efficiency and feasibility study on biomass gas use. Gyeonggi Research Institute 1-145

14. Korea Ministry of Environment (2018) 1st master plan of resource recycling (2018 2027)

15. Neo Research Co., Ltd. (2018) Status of biogas market and anaerobic digestion facilities, neorsc.com/gnuboard5/bbs/board. php?bo_table $=$ sub301\&wr_id $=45$

16. Korea Ministry of Environment (2015) Status of organic waste energy resource utilization facilities

17. Korea Ministry of Environment (2015) Official waste testing method

18. Korea Ministry of Environment (2015) Official Testing Method with respect to water pollution process

19. National Institute of Environmental Research (2014) Guideline of biogasification in Germany

20. Ministry of Food and Drug Safety (2015) Official Food Testing Method

21. Angelidaki I, Sanders W (2004) Assessment of the anaerobic biodegradability of macropollutants. Rev Environ Sci Bio 3:117-129

22. Tchobanoglous G, Theisen H, Vigil S (1993) Integrated solid waste management. McGraw-Hill, NY

23. DeLong EF (1992) Archaea in coastal marine environments. Proc Natl Acad Sci 89:5685-5689

24. Ovreås L, Forney L, Daae FL, Torsvik V (1997) Distribution of bacterioplankton in meromictic Lake Saelenvannet, as determined by denaturing gradient gel electrophoresis of PCR-amplified gene fragments coding for 16S rRNA. Appl Environ Microbiol 63:3367-3373

25. Lee DJ, Moon HS, Bae JS, Ki DJ, Yoon GT, Jeon TW, Lee YK (2017) Technical guideline of integrated treatment of organic waste in the biogasification facility-2nd edition. NIER Environmental Resources Research Department

26. FitzGerald JA, Allen E, Wall DM, Jackson SA, Murphy JD, Dobson AD (2015) Methanosarcina play an important role in anaerobic co-digestion of the seaweed Ulva lactuca: taxonomy and predicted metabolism of functional microbial communities. PLoS ONE 10(11):e0142603

27. Rabii A, Aldin S, Dahman Y, Elbeshbishy E (2019) A review on anaerobic co-digestion with a focus on the microbial populations and the effect of multi-stage digester configuration. Energies 12(6):1106

28. De Vrieze, J. (2014) Methanosaeta vs. Methanosarcina in anaerobic digestion: the quest for enhanced biogas production (Doctoral dissertation, Ghent University)

29. Kim JH, Kim SK, Hwang IJ, Ahn JH, Kang SW, Lee WT, Lim JH, Lee JK, Lee TY (2014) A study on the biogasification of municipal and industrial wastewater sludge. J Korean Geo-Environ Soc 15(9):5-12

30. Byun BS, Lee JS, Bae JH, Song YH, Jun HB (2014) A study on optimum mixing ratio for the integrated digestion of organic waste and sewage sludge pretreated. J Water Treat 22(5):93-102

31. Kim SH, Han SK, Shin HS (2004) Feasibility of biohydrogen production by anaerobic co-digestion of food waste and sewage sludge. Int J Hydrogen Energ 29:1607-1616

32. Lee DJ, Bae JS, Seo DC (2017) Effect of seasonal variations of organic loading rate and acid phase on methane yield of food waste leachate in South Korea. Appl Biol Chem 60(1):87-93

33. Shin JD, Hong SG, Kim SC, Yang JE, Lee SR, Li FZ (2016) Estimation of potential methane production through the mass balance equations from agricultural biomass in Korea. Appl Biol Chem 59(5):765-773

34. Lee DJ, Bae JS, Seo DC (2018) Potential of biogas production from swine manure in South Korea. Appl Biol Chem 61(5):557-565

35. Lee SY, Yoon YS, Kang JG, Kim KH, Shin SK (2016) Anaerobic co-digestion characteristics of food waste leachate and sewage sludge. J KORRA 24(1):21-29

\section{Publisher's Note}

Springer Nature remains neutral with regard to jurisdictional claims in published maps and institutional affiliations. 